This item was submitted to Loughborough's Research Repository by the author.

Items in Figshare are protected by copyright, with all rights reserved, unless otherwise indicated.

\title{
Embedding multinational firms in regional business systems: neoliberal and social-democratic models in Spain
}

PLEASE CITE THE PUBLISHED VERSION

https://doi.org/10.1111/irj.12202

\section{PUBLISHER}

(C) 2018 Brian Towers (BRITOW) and Wiley

\section{VERSION}

AM (Accepted Manuscript)

\section{PUBLISHER STATEMENT}

This is the peer reviewed version of the following article: GONZALEZ, M.C. ... et al, 2018. Embedding multinational firms in regional business systems: neoliberal and social-democratic models in Spain. Industrial Relations Journal, 49 (1), pp.50-68, which has been published in final form at https://doi.org/10.1111/irj.12202. This article may be used for non-commercial purposes in accordance with Wiley Terms and Conditions for Use of Self-Archived Versions.

\section{LICENCE}

CC BY-NC-ND 4.0

\section{REPOSITORY RECORD}

Menendez, Maria C. Gonzalez, David Luque Balbona, Gabriel Pruneda, and Phil Almond. 2018. "Embedding Multinational Firms in Regional Business Systems: Neoliberal and Social-democratic Models in Spain". figshare. https://hdl.handle.net/2134/28128. 


\section{Introduction}

This paper explores how international competition to attract foreign direct investment (FDI) shapes the governance of regional business and employment systems in Spain. It highlights the importance of the sub-national regional level in institutional adaptation to the requirements of the international productive system (*ANONYMISED*2011; Beugelsdijk and Mudambi, 2013). Specifically, it analyses how regions organise their business and employment systems to compete for FDI, and the role of industrial relations actors within this.

In recent years, the growing mobility of productive capital has substantially modified the role of states as coordinators of the economy. Commentators speak of a shift from the Keynesian welfare state to the Schumpeterian workfare state, and from demand-side to supply-side interventions (Jessop, 1993). This has led to pressures for a "hollowing out" of the national state: “some state capacities are transferred to pan-regional, pluri-national, or international bodies; others are devolved to the regional or local level inside the national state; and yet others are assumed by emerging horizontal networks of power - regional and/or local - which by-pass central states and link regions or localities in several societies.” (Jessop, 1993: 10). Equally, capital mobility has played an important role in shifting relations between collective actors from traditions of confrontation in industrial relations to social partnership (Martinez Lucio and Stuart, 2005).

In this environment, and in a national governance context which gives substantial autonomy to sub-national regions, we focus on how regional governance may constitute an arena within which various social actors - governmental actors, the managers of firms, unions, employer organisations, and educational institutions, among others - attempt to "tailor” regional business systems to attract and retain investment (Phelps and Fuller, 2001). Through a comparative study of two Spanish regions, we show variations in the strategies deployed to 
attract and retain FDI, and in the involvement of different actors in these strategies. The research question addressed is which factors determine the choice of a particular mode of governance of regional business and employment systems. We demonstrate that the extent to which co-ordination mechanisms in the sphere of FDI competitiveness involve collective industrial relations actors is affected by ideological beliefs on the benefits of social partnership, but that the political power and legitimacy needs of ruling parties and the power of trade unions in regional governments also play a significant role, which may in combination be of even greater importance.

The paper is structured as follows. First, we present the analytical framework used in the research, alongside some important contextual features of the environment of regional political economies in Spain. We then present the methodology for our empirical research, before presenting results for the two regions examined - Asturias and Madrid. Finally, the discussion and conclusion consider reasons for our findings.

\section{Analytical framework and context}

Our analytical framework is based on how global production networks (GPN) structure, and in part are structured by, political exchange at regional levels. The GPN literature (Henderson et al, 2002; Coe and Yeung, 2015) is drawn upon because it goes beyond older, more static accounts of comparative institutional advantage, in focusing on the continual processes of adaptation between regional resources and the constantly evolving requirements of firms within GPNs. These requirements are seen as inherently dynamic; they are always, by definition, in a process of flux —in the process of becoming — both organizationally and geographically” (Coe et al. 2008: 272).

Analysing this dynamism requires a relational framework; "within a network framework, it makes sense to conceive of the firm as a relational network embedded in wider networks of 
social actors and institutions” (Coe et al. 2008: 277). Focusing on the relations between firms and territorial actors requires analysis of how regional social and political actors activate networks to respond to the requirements of international competition, and to attempt to embed lead firms with their territorial ambit (Henderson et al, 2002). This enables investigation of potential differences in the dynamics which may arise in different regions of the same national state: “despite certain path-dependent trajectories, regional development remains a highly contingent process that cannot be predicted a priori” (Coe et al. 2004: 469). Such research attempts to evaluate Sub-National Institutional Capacity, a concept derived from economic geography (Phelps, 2000). Following Monaghan et al (2014: 132), subnational institutions can be defined as "the body of local regulatory and service-providing institutions with a functional remit to engage with foreign-owned enterprise at a subnational level”. As Fuller et al (2003) argue, subnational institutional capacity in underpinning successful “economic spaces” rests on the organization, credibility, partnership and network relations of subnational actors towards a common unified purpose. Subnational governance actors try to organize themselves to create customized coalitions in order to compete for new and repeat inward investment.

Attempts to develop institutional capacity can develop in a wide variety of ways. *ANONYMISED* (2017), propose three ‘ideal type’ models - market-centred, statecoordinated and associational governance- while pointing out that coherent empirical regimes generally require elements of all three. This paper aims to reveal what determines the choice of one predominant model of governance over another at a regional level, in the context of a national state with substantial regional autonomy over economic governance. This is important for industrial relations as these choices structure the involvement in, or exclusion from, economic development regimes of collective industrial relations actors. 
Our hypothesis is that the leeway of each regional government in shaping co-ordination mechanisms towards the inclusion of unions and employers in the management of policies relevant for FDI is likely affected by its political beliefs on the benefits of social partnership, but is also shaped by the power and need of legitimacy of the ruling party, and by trade union power (Gallie, 2007). When the regional government is weak, and in a context of strong trade union power, it may choose to foster dialogue with social actors in order to gain social legitimacy and support for its actions. Agreements resulting from this dialogue may be seen as the expression of a "political exchange" through which unions are incorporated into public decision-making in exchange for their cooperation in the design and implementation of policy (Pizzorno, 1978). Under weak governments, such governance coalitions may increase the capacity to develop institutional competitive advantage by combining efforts in the same direction. Meanwhile, strong governments, with absolute majorities, enjoy more leeway to develop market or unilaterally-designed non-market coordination mechanisms, as they do not require the additional legitimacy provided by social partners to carry out their acts of government.

To understand the context in which these choices are made, before presenting our primary research, it is necessary to present some context on regional political economy within Spain. The 1978 Constitution led to Spain becoming the so-called "state of autonomies” (Moreno, 2002). Seventeen Autonomous Communities covering all the country were created with their own regional parliaments, executive governments, presidents, and high courts of justice. Regional parliaments' competencies are regulated by the respective autonomy statute of each region and their members are elected by universal suffrage every four years. The Spanish Constitution regulates the competencies that autonomous communities can assume from the central state. Some competencies, such as regional economic development policies, were devolved to the regions from the inception of the system in 1979-1983, when all regions’ 
autonomy statutes were passed and the first regional elections were held. Since then, the gradual transfer of powers from the central state to the regions continued and intensified in the mid-1990s. While not all regions have the same breadth of self-government, if we consider public spending to be a good indicator of the level of autonomy, they collectively enjoy a high level of self-government in comparative terms, with a share of $39 \%$ of overall public spending in 2013, while the central and local administrations represented $46.1 \%$ and 14.9\%, respectively, according to Eurostat.

In the sphere of industrial relations, while the IR system is determined at national level, regional governments - alongside employer associations and trade unions - have substantial capacity to opt for different modes of governance of regional development policy, allowing them to follow a more "liberal” or more "coordinated" model. By comparing two autonomous communities with clearly different political traditions, the Principality of Asturias and the Community of Madrid (hereafter, Asturias and Madrid, respectively), subnational variations in the system of co-ordination for attracting and retaining FDI in Spain are shown. The Madrid region has been in the last two decades emblematic of neo-liberal governance within Spain, while Asturias represents a strong case of regional level corporatism.

Regional governments enjoy a level of autonomy concerning some crucial socioeconomic competencies - human capital formation, employment, economic development, infrastructures and, to a lesser extent, industrial relations. Therefore, they can attempt to improve coordination in those areas that will improve the performance of the regional business system, for instance in the attraction and retention of FDI. Since regional actors possess a wide range of resources and political tools to address economic and social challenges (Royo, 2008), it is important to analyse the possible existence of varieties of region-state intervention in Spain. 
In the industrial relations context of Spain, inclusive regional policies tend to be associated with substantive regional social pacts, which represent a form of regional neo-corporatism non-market coordination mechanism sponsored by the (regional) government. In this context, corporatism can be understood, following Öbert et al. (2011: 36), “as a game that takes place in institutionalized arenas in which each actor controls resources that the others desire”.

Schematically, the government controls the production of regulation, fiscal policy and public expenditure and, if and when considered desirable, can invite the social partners to join the process of political determination. However, the social partners and in particular the trade unions are not reduced to a mere passive role. They also possess assets and resources which are desired by the government, namely the control of their affiliates. In this game of mutual reciprocities, active support by the social partners in the design and implementation of the measures taken by the government also implies a transfer of responsibility regarding the manufacture of public policies (*ANONYMISED*, 2015).

Figure 1. Corporatism as a process of political exchange

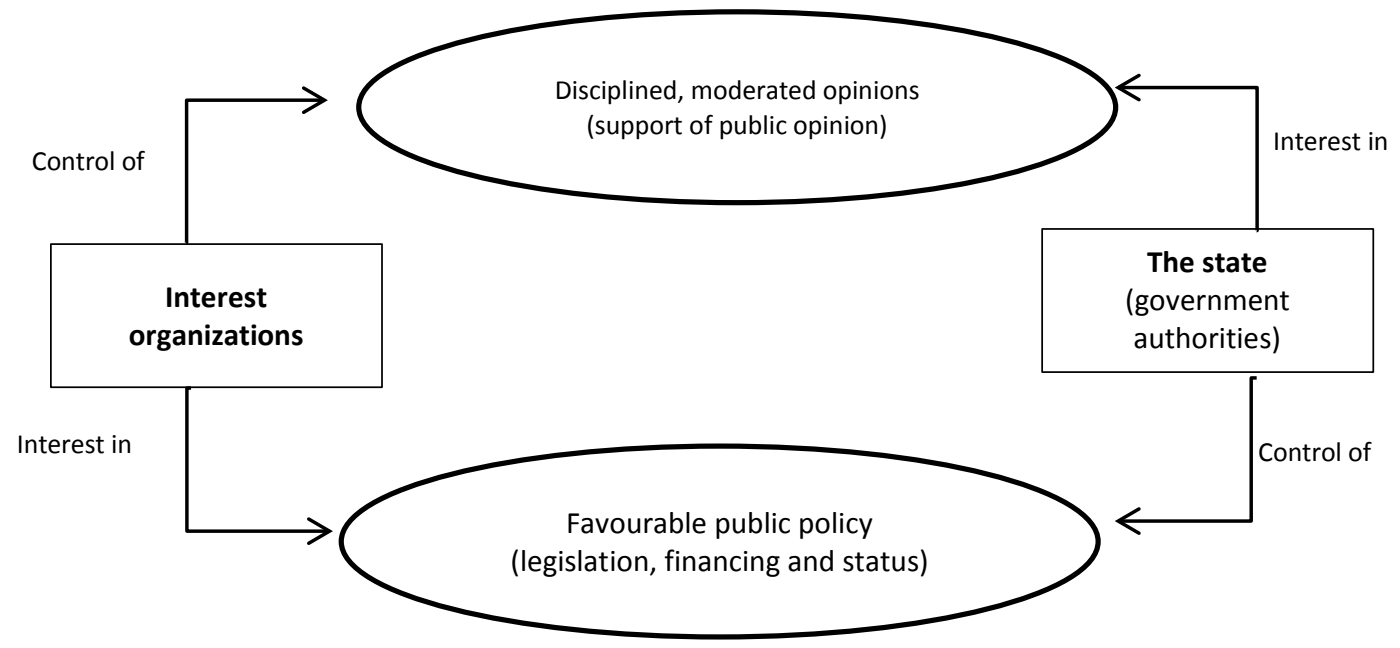

Source: Öbert et al. (2011: 368).

Of our two cases, Asturias has opted for a route in which social pacts and political exchange attempt to overcome historical social conflict and antagonism between industrial relations 
actors, in an attempt to reverse industrial decline. Globalising pressures, in this case, have resulted in increased capacities for coordination between the regional government and industrial relations actors. In contrast, Madrid, which has been dominated by conservative governments and has weaker trade unions, has opted for a predominantly liberal approach to the governance of its regional business system.

\section{Methodology}

We performed qualitative comparative research across two regions (Madrid and Asturias). This draws upon substantial desk research, based on the collection and analysis of a wide range of publicly available documents drawn from regional states, trade unions, employer organisations and press reports. Primary data was obtained by an iterative sampling method used to identify and then interview relevant actors in regional development, inward investment/economic development agencies as the first node, as these were considered the "main interlocutor" for foreign firms in a location. At the end of these interviews respondents were asked to identify other actors within the region who engaged with FDI. These were added to a provisional list of governance actors to interview. This process ensured that all active regional institutional actors were identified and that interviewees were individuals holding prominent roles in regional development according to some other actor/s interviewed. As a result, managers of regional development agencies, officers of the regional government, union, employers and business representatives, representatives of research and innovation organisations, and of training organisations, were interviewed. The resulting interviews show the different pattern of relevant actors in each region. The network of actors involved in the process of attracting and retaining FDI incorporates a wider range of actors and institutions in Asturias than in Madrid: in the latter, for instance, unions and employers' associations were not identified as stakeholders. As a control method, an interview with a representative of a 
main trade union in Madrid corroborated the exclusion of trade unions in this area. In total, 27 interviews were conducted were interviewed in 2010-2015 (see table 1).

Table 1. Interviews and interviewees

\begin{tabular}{|l|r|r|r|r|r|r|}
\hline & \multicolumn{3}{|c|}{ Interviews } & \multicolumn{3}{l|}{ Interviewees } \\
\hline Institution/organization & A & M & Total & A & M & Total \\
\hline Regional government authorities & 3 & 3 & 6 & 3 & 3 & 6 \\
\hline Regional Development Agencies & 2 & 3 & 5 & 2 & 5 & 7 \\
\hline Local Development Agencies & 1 & 1 & 2 & 1 & 3 & 4 \\
\hline Educational or regulatory institutions & 4 & - & 4 & 5 & - & 5 \\
\hline Public and semi-public R\&D / ICT agencies & 3 & - & 3 & 3 & - & 3 \\
\hline Trade Unions & 2 & 1 & 3 & 3 & 1 & 4 \\
\hline Employer associations & 1 & - & 1 & 1 & - & 1 \\
\hline Business associations & & & & & & \\
\hline Total & 19 & 8 & 27 & 21 & 12 & 34 \\
\hline
\end{tabular}

Note: A (Asturias); M (Madrid)

Interviews were based on a semi-structured questionnaire and engaged with respondents for approximately 90 minutes, extending to two hours per respondent on occasion. The interviews were recorded when permission was granted by the participants, whose anonymity was guaranteed. All interviews were transcribed (except in one case where recording was not permitted), coded and analysed using NVivo.

FDI and economic development regimes in Asturias and Madrid compared 
As we introduced above, Asturias approximates to a social-democratic governance of a distinctly neo-corporatist flavour, while Madrid has opted for a much more 'liberal' model. The following sections present how and why these decisions were taken, and the implications for industrial relations.

\section{Asturias: a social democratic model of governance}

Asturias is located in the northwest of the country, with approximately one million inhabitants. Until recently its economy was dominated by basic industry -coal, steel, and shipbuilding - sectors ran by large national firms until the reconversion and privatisation processes that took place from the 1980s onwards. The metal sector remains the economic engine of the region. From the 1980s, as in other regions suffering a similar structural crisis, attracting FDI was emphasized in order to further economic development and to modernise the region’s productive network (Government of the Principality of Asturias, 2014a).

The takeover by foreign capital of some of the main manufacturing firms in Asturias, together with some new investments in the 1990s and 2000s means that FDI gained particular

relevance in terms of employment. The industrial sector is dominated by a reduced number of large multinational manufacturing firms, such as Arcelor-Mittal (steel), Alcoa (aluminium), Saint-Gobain (glass), DuPont (chemicals), ThyssenKrupp (escalators), and Xtrata (zinc). More recently, the region has seen the settlement of ICT multinationals such as CSC, Capgemini and Software AG. The regional productive ecosystem therefore is characterized by the presence of large "regional champions", generally foreign-owned, surrounded by smaller domestic firms which lack the resources to compete on an international level. This strengthens the incentives for state and social actors to develop non-market mechanisms of coordination. 
As to self-perception, Asturias’ website for foreign investors highlights its highly qualified active population, deep-rooted industrial history and innovative ecosystem, a higher than national average productivity at competitive labour costs, low labour turnover, the high quality of public services, its seaports, and its numerous economic development programmes, particularly supporting the manufacturing and industrial support services sectors (IDEPA, 2015).

The Statute of Autonomy of Asturias came into force in 1982 and with it the mandate for regional development. The socialist party (PSOE), with a social-democratic orientation, has won seven of the nine regional elections held so far. The hegemony of the socialist party in the region was interrupted only twice. The conservative People's Party (PP) held office in 1995-1999 and a regionalist conservative party in 2011-2012. From 2003, minority socialist governments were most often supported by a coalition that included a party to the left of the socialists in the political spectrum, while in 2014 they required support from the PP to approve the 2015 regional budget.

Trade unions have a clear influence over any Asturian government because of high trade union membership. As a consequence of its heavy industry tradition, the unionisation rate of 31.4\% in Asturias is the highest in Spain, nearly twice the national average of 16.4\% (MESS, 2011). UGT is the main trade union with around 3,500 delegates, representing $43 \%$ of union representatives in the region overall, and has exceptionally tight links with PSOE in Asturias (Vega García, 2011). Part of UGT is SOMA (the acronym in Spanish from Asturian Mining Labourers Union), a union deeply rooted in the history of the labour movement that has considered it necessary to harmonize the defence of workers with political participation since its foundation in 1910. The influence of SOMA on the socialist party is strong and its 19792013 leader was, simultaneously, a socialist elected member of the Asturian Parliament . The regional employers’ association (FADE) is also relatively strong in membership terms, 
representing 39.8\% of employers (as opposed to a national average of 28.5\%, Encuesta Laboral Anual, 2013).

Social dialogue has been the hallmark of the style of the regional government in Asturias over the past two decades, with social pacts resulting from tripartite social dialogue operating as the framework of reference for the management of regional employment policy. Asturias has developed increasingly overarching and strong four-year employment-focused social pacts since 2000, with a pilot in 1996 having been conducted by a minority conservative government under the auspices of the European Union. The sequence of social pacts between the regional government, and the regionally most representative trade unions and employers' association is shown in Table 2.

Table 2. Tripartite social pacts in Asturias

\begin{tabular}{|c|c|c|c|}
\hline Agreements & Year & Signatories & Main contents \\
\hline \multicolumn{4}{|l|}{ Asturias } \\
\hline $\begin{array}{l}\text { Territorial Pact for } \\
\text { Employment in the } \\
\text { Mining Districts }\end{array}$ & 1996 & $\begin{array}{l}\text { Regional government } \\
\text { (PP, minority } \\
\text { government), Asturian } \\
\text { Local Councils } \\
\text { Federation, FADE, } \\
\text { UGT y CCOO }\end{array}$ & $\begin{array}{l}\text { Employment creation } \\
\text { measures }\end{array}$ \\
\hline $\begin{array}{l}\text { Institutional Pact for } \\
\text { Employment }\end{array}$ & 2000 & $\begin{array}{l}\text { Regional government } \\
\text { (PSOE, absolute } \\
\text { majority), FADE, } \\
\text { UGT y CCOO }\end{array}$ & $\begin{array}{l}\text { Active employment policies; } \\
\text { industrial policy; training; } \\
\text { health and safety at work }\end{array}$ \\
\hline $\begin{array}{l}\text { Agreement for } \\
\text { Economic } \\
\text { Development, } \\
\text { Competitiveness and } \\
\text { Employment }\end{array}$ & 2004 & $\begin{array}{l}\text { Regional government } \\
\text { (PSOE-IU), FADE, } \\
\text { UGT y CCOO }\end{array}$ & $\begin{array}{l}\text { Economic promotion } \\
\text { policies; employment and } \\
\text { vocational training } \\
\text { promotion; health and safety } \\
\text { at work; social cohesion; } \\
\text { public investment }\end{array}$ \\
\hline $\begin{array}{l}\text { Agreement for } \\
\text { Competitiveness, } \\
\text { Employment and } \\
\text { Welfare of Asturias }\end{array}$ & 2008 & $\begin{array}{l}\text { Regional government } \\
\text { (PSOE-IU), FADE, } \\
\text { UGT y CCOO }\end{array}$ & $\begin{array}{l}\text { Economic promotion; } \\
\text { knowledge society and } \\
\text { economy; employment and } \\
\text { training; health and safety at } \\
\text { work; public investment; } \\
\text { social cohesion }\end{array}$ \\
\hline $\begin{array}{l}\text { Agreement for } \\
\text { Employment and } \\
\text { Progress of Asturias }\end{array}$ & 2013 & $\begin{array}{l}\text { Regional government } \\
\text { (PSOE, with IU and } \\
\text { UPD support), FADE, }\end{array}$ & $\begin{array}{l}\text { Employment promotion } \\
\text { agenda; business and } \\
\text { industrial revitalisation; }\end{array}$ \\
\hline
\end{tabular}




\begin{tabular}{|l|l|l|l|}
\hline & & UGT y CCOO & $\begin{array}{l}\text { welfare state protection; } \\
\text { public investment }\end{array}$ \\
\hline $\begin{array}{l}\text { Agreement for } \\
\text { Economic } \\
\begin{array}{l}\text { Competitiveness and } \\
\text { Social Sustainability }\end{array}\end{array}$ & 2016 & $\begin{array}{l}\text { Regional government } \\
\text { (PSOE, with IU } \\
\text { support), FADE, UGT } \\
\text { y CCOO }\end{array}$ & $\begin{array}{l}\text { Improvement of the } \\
\text { competitiveness; Labour } \\
\text { insertion and improved } \\
\text { employability; Sustainable } \\
\text { territorial development; And } \\
\text { innovation and social } \\
\text { sustainability. }\end{array}$ \\
\hline
\end{tabular}

Source: own elaboration.

Social pacts in Asturias have been configured in a manner similar to parliamentary pacts, i.e. with detailed records of actions, committed budget allocations, and monitoring committees. The pact in force at the time of writing (2016-2019) committed 1,742 million euro (AECSS, 2016). In 2015, 24\% of the total regional budget was governed by the social pact. In the words of one of our interviewees, it is "a kind of co-government" with social partners. Successive regional governments have involved social actors in the design and implementation of economic development policy, via such pacts. This has generated a dynamic of collaboration on regional governance: the search for consensus, believed to be a source of social cohesion (CESA, 2014), is a characteristic that is seen as key for the economic development of the region:"The change of political and economic circumstances represents significant challenges to face in this new stage of Regional Pact where, once again, consensus becomes crucial to the economic and social development of Asturias” (AEPA, 2013: 5).

Since social pacts have been led by the trade unions, industrial peace was one of the main outcomes of corporatism in the region. After leading for decades the strike activity rate, over the period 2004-2014 Asturias progressively converged with the national average of about 70 days not worked per 1000 employees (*ANONYMISED*, 2010). A second outcome is a better understanding between trade unions and employers. This is shown by the progressive incorporation of the employers' agenda to the pacts, increasingly adding to their original 
focus on social cohesion (employment, territorial development, social sustainability) with an increased focus on economic competitiveness, to the point that they are presented in the last agreement as two indivisible elements for the development of the region (ACESS 2016, p.4). A third outcome is the greater efficacy of the socio-economic policies agreed to. Finally, trade unions and the employer federation have also gained social visibility and economic resources as a result of the institutional participation entailed by the social pacts. Whether this tradition of corporatism will survive the on-going generational change at the leadership of the trade unions, the socialist party and the employers' federation is an open question.

The extensive involvement of industrial relations actors in the economic strategy of Asturias is well-reflected in the process of development and execution of the Regional Innovation Strategy (RIS3) which fell to the tripartite governing council of the regional development agency. After being discussed on two separate occasions, the strategy was approved unanimously in 2014.Social partnership at firm-level

While regional social pacts are government-led, evidence of previous autonomous industrybased co-ordination by the social partners can also be found in Asturias. Particularly important in this regard are the set-up of the Construction Labour Foundation (CLF) in 1988, and the signing of the Oviedo Pacts in 1993. The CLF is a bipartite and non-for-profit foundation established by an industry region-wide collective agreement, funded by the employers, and aimed at providing specific services to workers (training, healthcare). The Oviedo Pacts, in force since 1993, regulate the industrial relations in the auxiliary industry of the largest private firm in Asturias. Signed by the unions, the regional government and ArcelorMittal, it was the result of a 40-day strike and is renewed every five years. In the event of an auxiliary firm losing the contract with ArcelorMittal, its employees are transferred to the company winning the contract. In exchange, production in the so-called 'hot phase', i.e., when the stoppage of a facility would entail irreparable damage, is guaranteed. 
At firm and establishment levels, competitive pressures deriving from globalization have created new interactions between employers and collective labour, as part of an overall shift from adversarial relations to attempts to establish 'new' labour-management partnerships for 'mutual gain' in the region (see Martinez Lucio and Stuart. 2005).

“As trade unions we also had to adapt (...). We had to... and more so lately, we've had to talk about flexibility, of functional flexibility, of... of wage freezes, (...) In other words, trade unions have put a lot of effort” (Asturias trade union official).

This dynamic of "corporate-level political exchange" has sometimes involved atypical deals by foreign firms. For example, in one large MNC “At Asturias we did something rather novel back in the day. When the first investment was made there we decided, before hiring any worker, to negotiate with the trade unions a collective agreement for the factory [...]. We bet on an IR framework in which the central regional union federations participate” (Manager of MNC with productive centres in Asturias and Madrid).

Equally, in some cases, collective responses were sought in response to the post-2008 crisis. For example, in one medium-sized MNC unit,

"We sat down with the committee. We had to stop the plant from $15^{\text {th }}$ December to $19^{\text {th }}$ January. We took holidays. This was between 2008 and 2009. We took the holidays of several years, up to those of last year. Whatever were needed. People took the holidays of 2008, 2009, 2010 and 2011. It did not matter. Everyone took them ahead of time without problems. When we recovered the workload all went back to normal. This makes us a bit atypical- It gives us flexibility which is what the clients demand”. (Manager of MNE in Asturias). 
The economic importance for the region of a small number of MNEs fosters a collaborative attitude among trade unions and government. Engagement in co-operative-based partnership therefore 'involves an acknowledgement on both sides of their mutual exposure to risk' (Deakin et al., 2005: 64). In some cases, restructuring pacts in key industrial firms have been crucial to their economic stabilization. Such alliances have been also favoured by the presence of locals in high managerial positions in many of the most important MNEs. Such managers are often concerned both with the survival of the business and with the regions' economic development, and they address both by pursuing renewal and widening current investment.

\section{Other examples of non-market forms of economic coordination}

The implementation of active employment policies is a competency of the regions. In Asturias, the 2004 social pact specified the establishment of the Public Employment Services (PES) as an autonomous organism, with the unions and employer association as board members. Social partners are also, according to all interviewed, effectively present in the design and evaluation of regional vocational training plans, first, via the regional social pact which sets out the main lines of the regional programme on vocational training, and second, and more specifically, via the advisory Asturias Council of Vocational Training.

Regarding the organisation of specific services for foreign firms' attraction and retention, the attraction and retention of FDI in Asturias is part of the portfolio of a public entity charged with contributing to overall regional economic development that is supervised by the regional government, the trade unions and the employers' association. IDEPA (the Institute for Economic Development of Asturias) is a public entity, embedded in the regional administration, created in 2002 to foster a balanced and sustainable regional economic growth. Its tripartite governing council includes the regional government, the trade unions and the employers (Government of the Principality of Asturias, 2014b), and its budget in 
2015 was 22.7 million euro. It develops general programmes aimed at the promotion of productive investment, the creation of new companies, the expansion of local firms in foreign markets, and the improvement of business competitiveness through training, innovation and co-operation. It also acts as a 'one-window' service for investors, supporting projects that have the potential to modernise and diversify the region's industrial fabric. An important part of that support is advising potential investors, anticipating their needs and offering them tailored solutions, including financial support.

\section{MADRID: A NEOLIBERAL MODEL OF GOVERNANCE}

\section{Overview of economic structure and governance actors}

The region of Madrid hosts the political-administrative capital city of Spain and has over 6 million inhabitants. The services sector leads the economic activity of Madrid, reaching 85\% of the total. Besides housing most of the central administration of the state, it is also host to many national and foreign firms' headquarters, particularly in the financial and business services sectors.

Taking into account that Madrid has attracted more than half (59\%) of the overall FDI in Spain during the last two decades it is perhaps unsurprising that an Asturian employers' representative referred to Madrid as a "black hole, sucking everything in” in reference to FDI in Spain. As to self-perception, Madrid's website highlights, among others, the large market of the region, being the 3rd financial centre of Europe and 4th in the world, the extensive presence of foreign and Spanish firms, its favourable tax policy, its expenditure on R\&D and its advanced research and development institutes (Invest in Madrid, 2015).

The Statute of Autonomy of the Community of Madrid was approved in 1983. The PSOE held the presidency of the regional government between 1983 and 1995 (although without an 
absolute majority after 1987). From 1995 onwards, the PP was in office and by absolute majority - the current government (since 2015) and a few months in 2003 excepted.

Union membership in Madrid is only $11.8 \%$, one of the lowest rates in the country. Of the two major trade unions in Spain, CCOO is the largest, with $40.3 \%$ of overall union representatives in the region. The relationship between trade unions and the successive regional PP governments in Madrid deteriorated, especially since 2003. The 2003-2012 President of the Government of Madrid, Esperanza Aguirre, often exhibited publicly her dislike of trade unions (El Mundo, 2012). Courts found illegal, as abusive, the minimum services imposed on striking workers by her governments in several occasions. The institutional relation between trade unions and regional government was minimal (see below).

Madrid also became the centre of many of the public sector labour protests known as 'mareas' (tides) that followed the economic crisis: White (health), Green (education), Orange (social services) and Black (rest of public administration). Mareas represented an innovative form of mobilisation and protest against austerity measures, unifying class-based trade unions, profession-based trade unions and public services customers (*ANONYMISED*, 2016).

The Regional Employer Association of Madrid, CEIM, also has a lower rate of affiliation (23.7\%) than the national average (28.5\%) and that found in Asturias (39.8\%). This points to a weak capacity to organize the region's employers.

Exploiting the organizational and political weaknesses of trade unions and of the employers' association, the Madrid regional state epitomises the neoliberal currents within Spanish politics, which have been increasingly focused on undermining non-market forms of economic coordination (*ANONYMISED*, 2013). 
The region, with a highly diversified productive profile as to MNEs, does not depend on a handful of large ones such as it is the case of Asturias. As a consequence, relations of the regional government with each MNE are not as close. A manager at the Madrid subsidiary of a MNE with productive centres in other parts of Spain complained of getting less attention in Madrid.

"We can compare with another centre in another Autonomous Community. The activity of the regional administration with the firm there is much superior. Here we are just one of many” (Manager of industrial MNE, Madrid).

The manager also pointed out the concentration of effort of the regional government on services.

"It is very difficult, not just for us, for all manufacturing businesses, to make them conscious of the importance of the sector, to get them to give us the same love they give to services... [...] they [the regional government] love the financial service... [...] The purest hardest of manufacturing, us, we have problems...”. (Manager of industrial MNE, Madrid).

Institutional building of coordination mechanisms of the regional business system

In Madrid, the first regional social pact was the Pact for Industry and Employment, signed in 1993, under the auspices of a minority socialist government (Table 3). This strategy of consultation was continued in the following conservative government with the 1995 Pact for the Creation of the Madrid Council for Development, Employment and Training. However, the 2003 arrival to the regional presidency of Esperanza Aguirre, a declared admirer of Margaret Thatcher, marked the beginning of a clear neo-liberal shift in regional policy, towards the exclusion of social actors and towards an open confrontation of the regional government with the unions. Under her presidency two prototypically weak pacts - i.e. including general objectives and declarative commitments, few detailed measures, and no 
financial commitments (Aragón et al, 2008: 24) - were signed. The 2004 Agreement for Employment and Economic Growth and the 2009 Agreement for Economic Reactivation and Employment in the Community of Madrid, were particularly formalistic and ceremonial agreements. In the words of one of our interviewees, when asked about regional social pacts:

"Here that is gone. There was one, fairly rhetorical, on supporting business activity signed with González. With Aguirre there had been another, extending the previous one, on which we could agree on some issues, but the next she wanted it was... (laughs). In brief, it couldn't be signed, not a chance. She did not want it to happen. It was not of interest for them. No real intention. And the current one looks much the same: very few issues... only the most aseptic ones, such as supporting business activity... which will have little impact and little money attached. When you aim to other issues, such as was the case in the one signed with Gallardón, or the case of the education pact ... That was years ago, that is not happening. Nothing, there is nothing. They do not want social concertation. Social dialogue in Madrid now... they are allergic to it.” (Madrid trade union official)

The progressive estrangement of trade unions from the actions of the regional government was manifested by their dissent, expressed in advisory reports of the Economic and Social Council of Madrid - a tripartite consultative body of the regional government in social and labour matters - towards regulatory projects of the regional government. However this body was increasingly ignored by the regional government.

"The Madrid Council, that meets twice a year, where the employers' association and trade unions indeed are represented, is supposed to deal with employment and training matters, but then ... there is no real participation. They inform you or send you draft reports regarding the measures they intend to take for your opinion (laughs), you send it through, they send it back, then they do what they want" (Madrid trade union official). 
The change of attitude towards social dialogue of successive PP governments culminated in 2013 with the closure of this body. The Aguirre government also reduced the number of work councils (from 120 to 36), as well as virtually halving the number of trade union hours per month in the public administration.

\section{Table 3. Tripartite social pacts in Madrid}

\begin{tabular}{|l|l|l|l|}
\hline Agreements & Year & Signatories & Main contents \\
\hline $\begin{array}{l}\text { Pact for Industry and } \\
\text { Employment }\end{array}$ & 1993 & $\begin{array}{l}\text { Regional government } \\
\text { (PSOE, minority } \\
\text { government), CEIM, } \\
\text { UGT y CCOO }\end{array}$ & $\begin{array}{l}\text { Industrial development; } \\
\text { training; employment and } \\
\text { industrial relations; } \\
\text { industrial land and } \\
\text { infrastructures }\end{array}$ \\
\hline $\begin{array}{l}\text { Pact for the Creation of } \\
\text { the Madrid Council for } \\
\text { Development, } \\
\text { Employment and } \\
\text { Training. }\end{array}$ & 1995 & $\begin{array}{l}\text { Regional government } \\
\text { (PP, majority } \\
\text { government), CEIM, } \\
\text { UGT y CCOO }\end{array}$ & $\begin{array}{l}\text { Creation of Madrid } \\
\text { Council for } \\
\text { Development, } \\
\text { Employment and } \\
\text { Training }\end{array}$ \\
\hline $\begin{array}{l}\text { Agreement for } \\
\text { Employment and }\end{array}$ & 2004 & $\begin{array}{l}\text { Regional government } \\
\text { Economic Growth } \\
\text { CEIM, UGT y CCOO }\end{array}$ & $\begin{array}{l}\text { Moving towards full } \\
\text { employment; } \\
\text { improvement of job } \\
\text { quality and stability; } \\
\text { work-life balance }\end{array}$ \\
\hline $\begin{array}{l}\text { Agreement for Economic } \\
\text { Reactivation and } \\
\text { Employment in the } \\
\text { Community of Madrid }\end{array}$ & 2009 & $\begin{array}{l}\text { Regional government } \\
\text { (PP absolute majority), } \\
\text { CEIM, UGT y CCOO }\end{array}$ & $\begin{array}{l}\text { Modernisation and } \\
\text { funding of SMEs; } \\
\text { training and labour } \\
\text { intermediation }\end{array}$ \\
\hline
\end{tabular}

Source: own elaboration.

There is little question about the Madrid PP being the most neo-liberal branch of the party, but the start of the open confrontation between the regional government and the unions can be traced back to 2007, when the general secretaries of UGT and CCOO in Madrid explicitly advised voting for left parties in local and regional elections. The gradual deterioration of relations between successive regional governments with trade unions led Madrid, which only represented $5.6 \%$ of the total number of days not worked due to strikes during 2009-2011, to see the figure rise to $20 \%$ in the following three years. 
Finally, the non-involvement of trade unions in the economic strategy of Madrid is wellreflected in the process of development of the Regional Innovation Strategy (RIS3). The governance of the Madrid RIS3 strategy fell to a committee integrating the regional government, representatives of businesses (clusters, firms, CEIM, Chamber of Commerce), and research agents (Government of the Community of Madrid, 2014). Trade unions were not included in the process of strategic reflection and choice of priorities.

Evolution of the management of public employment services, employment-oriented vocational training, and specific services for foreign firms

From 1993, as a result of national-level social dialogue, social actors participated in all stages of the vocational education and training policy process, from design to implementation, through the national Fundación Tripartita para el Empleo and in the regional boards of public employment services (PES), and managed substantial training funds in Spain. A reform in 2015 substantially reduced the social actors' role in the system’s governance (*ANONYMISED*, 2015), a change in which Madrid was a pioneer. Conversely to Asturias, the advisory bodies on vocational training for employment -all with social actor representation: Council for Development, Employment and Training; Vocational Training Council; Qualifications Regional Institute - were increasingly not used in Madrid. "We were usually consulted at the time, but then, the Vocational Training Council has not met since December 2006; at the Qualifications Regional Institute [created in 2006] we had a technical committee and the last meetings were in mid-2007, then they knocked it off [in 2010]. The Regional Employment Service later disappeared." (Madrid trade union official). Madrid, as part of its austerity measures, had already eliminated its PES in 2011, transferring the provision of the service to the Department of Employment of the regional public administration, thus eliminating direct supervision by unions and employers. 
Regarding the organisation of specific services for foreign firms' attraction and retention, in Madrid has dismantled its regional development office and provides services to foreign investors through a specific semi-public agency in partnership with a chamber of commerce. Invest in Madrid is the public-private agency in charge of attracting and retaining foreign direct and capital investment in Madrid, and that is its only goal. It is a joint agency of the Chamber of Commerce of Madrid and the Community of Madrid. Besides attracting foreign investment and promoting the image of Madrid as an investment destination, it provides advice on all possible matters for potential investors, including support for new projects of foreign investors already present in the region. The budget allocated to this agency and another related project in 2015 was 1.1 million euro. Previously, the attraction and retention of FDI was responsibility of PromoMadrid, a public agency created in 2004 that had a budget of 6.8 million euro and 44 employees in 2012, but which was closed in 2013. The regional development office, IMADE, had been closed previously, in 2011.

\section{Discussion}

The regions analysed have chosen different paths to respond to increasing competitive pressures. Asturias, of long social-democratic tradition and with high trade union membership, has integrated social actors in the design of regional economic policy through the successive approval of increasingly overarching social pacts. Equally, regarding the management of public employment services and training for employment, both major levers at the regional level to form an attractive workforce for investment, two opposing institutional designs took place, the incorporation of social partners in Asturias and their exclusion in Madrid. Similarly, with respect to the agencies responsible for attracting and retaining FDI, in Asturias this is done by a public regional development agency overseen by social partners, while Madrid has recently opted for a specialised public-private agency. In 
general, therefore, in Asturias, the regional government chose to incorporate socio-economic actors into the development of new institutional initiatives, led by the public sector, in order to build capacities for the coordination of the regional business system, moving towards a more coordinated model. In Madrid, meanwhile, the government chose unilateralism and the exclusion of trade unions from the design and implementation of regional development policy, giving more weight to private sector initiative and moving towards a more liberal model.

It is difficult to evaluate the success of regional inward investment regimes. The definition of desirable outcomes is inherently a political question; maximising the value of FDI is not necessarily a socially desirable target, given that the measures needed to do this in terms of domestic business and employment system regulation may often act against a broader interest of creating 'good jobs' in regional communities. Equally, inward investment statistics, particularly at regional levels, are highly volatile, and frequently distorted by merger and acquisition activities and other non-local developments in the market for corporate control. That said, on their own terms both the Asturias and Madrid regimes are relatively successful in a Spanish context. Both have a substantially higher proportion of foreign-owned business than the Spanish average. More broadly Asturias has managed to form close links with a number of large MNCs, in which it has won investment mandates including highly-prized global R\&D centres, allowing it to challenge, relatively successfully, earlier narratives of industrial decline (Kohler et al, 1996). Madrid, meanwhile, has over the last two decades begun to develop an effective pitch as a global city (Sánchez Moral et al, 2008), and captures large volumes of investment in financial and business services.

Both regions may be representative of more general models. The dynamics of regional corporatism present in Asturias can also be observed in other regions with socialist hegemony, such as the paradigmatic case of Andalusia, governed by the socialists since 1978. 
In the Valencian Community, immediately after the constitution in 2015 of a new coalition government led by the socialists, regional dialogue was resumed after ten years of paralysis with successive conservative governments. Meanwhile, Madrid, ruled by the conservative party for the last two decades, moved away from the general trend of regional governments toward tripartite social dialogue. In Madrid "there is no social dialogue at the institutional level, since participation instruments have disappeared" (CES, 2015: 332). Madrid was not alone: in 2014 social dialogue was virtually non-existent in Cantabria, La Rioja and the Valencian Community, all regions governed by absolute majority by the conservatives. The dependence of strategies for regional coordination of business systems on the composition of regional governments may lead them to lack a structural consistency in the medium and long term. The emergence of the new political parties Podemos and Ciudadanos, both questioning the status quo, may lead to institutional change. Podemos has been particularly critical of the institutional presence of the social actors in Asturias' governance, for they consider them part of the 'old' politics. Thus, with a minority socialist government following the May 2015 regional elections, the Economic and Social Council of Asturias, the main body for regional concertation, was abolished in late October 2017, at the initiative of the conservatives supported by Podemos and Ciudadanos. The law foresees the creation, within six months, of a new consultative council connected to the regional administration to guarantee the institutional participation of social actors. Yet, corporatism may have been weakened by this development. In Madrid, where the new conservative regional government depends on the support of Ciudadanos, unilateral decision-making may need revision.

In short, regional governments, following their political orientation and the relative power of trade unions, differ in terms of their choice of non-market coordination mechanisms regarding the regional business system. For a long time Madrid has followed a path of unilateral decision-making and an inclination towards a liberal model, while Asturias 
incorporated social actors to economic decision-making. It is worth remarking that most strong social pacts in both regions were signed by minority governments, the only exceptions being the 1995 Madrid one, signed in the first year of the first government of the PP, and the 2000 Asturias one. This shows that the promotion of social concertation at the regional level in Spain may be affected by the political beliefs of ruling parties, but also, and arguably to a greater extent, by their need for legitimacy and by trade union power.

\section{Conclusion}

One major contribution of this paper is to highlight the importance of regional governments in the political economy of industrial relations in a decentralized state in a context of reorganisation of productive capital into global production networks (Coe et al, 2008). The continual process of adaptation of host economy human and other resources to the constantly evolving needs of firms within global production networks may lead to trade unions being involved in, or excluded from regional networks aimed at creating successful economic spaces (Fuller et al, 2003).

Our analysis shows that regional governments are key decision-makers in determining the type of regional governance of FDI in Spain, with important structuring effects on the nature of direct interactions between the region state and specific multinational firms, and particularly, on the governance of wider regional business systems as to the degree to which social actors are included in or excluded from the relevant policy-making processes.

The second major contribution of this paper lays in stressing the role played by labour politics in regional economic governance. The recourse to neo-corporatist solutions to problems of coordination is also shaped by the power and legitimacy needs of regional governments, and by union power (Gallie, 2007). The perceived need to share governance with social actors is stronger when regional governments consist of cross-party coalitions, or 
minority governments dependent on the tacit approval of other parties, than on the occasions where a single party gains an absolute majority in regional parliaments.

It is important to stress that governmental actors in both regions have sought to defend and advance an entrepreneurial logic of action that requires cooperative exchange between business system actors. The differences lie mainly in the institutional logic of action as to the actors included in governance complexes. In Asturias regional state power has been used to promote an associational governance of FDI, while in Madrid the region state has strongly promoted market-based governance. While for unions involvement in inward investment regimes is not without its risks, it has, in the case of Asturias, been beneficial in at least two ways: first, it has helped secure 'good’ jobs through ensuring stability in industrial relations; and second, it has enabled the development of a regime which accommodates labour concerns, partly through substantive and encompassing social pacts and other institutional involvement.

In order to go beyond the specificities of the two regions involved, and to attempt theoretical generalisation, it is worth considering possible strategies for explaining these differences within the ambit of a single national business system. These can be summarised as a combination of explanations based on notions of path dependency, rational choice and power resources.

In terms of path dependency, clearly the Spanish national business system is at the permissive end of the spectrum in allowing for different patterns of coordination at regional levels. This can be traced back to the formation of the autonomous communities upon the restoration of democracy: lacking strong national scripts for how regional economic governance ought to work, regional actors had both the space and resources to engage in institutional experimentation (Kristensen and Zeitlin, 2005) with, in comparative terms, relatively little 
direct interference from national government. This means that the national business system is modulated at regional level on the basis of economic, social and political power structures.

Regional governments respond to the economic uncertainties and risks facing them. In the case of a capital city-region, these uncertainties are fairly diffuse in that there are many potentially mobile firms, each with a relatively small share of the economy and of employment; facing such an unspecific risk the Madrid region is predisposed to embrace the similarly diffuse market logic of competitive survival. In the case of a peripheral industrial region, capture of the regional political economy by firms is much more concentrated on a small number of large units of foreign multinational firms. When facing a very specific wellknown risk with potential devastating consequences, a bureaucratic logic of shared responsibility and co-operation to reduce uncertainty is a logical collective response. However, this remains contingent on the existence of a strong labour movement with substantial influence on state policy (Gallie, 2007). It is also worth briefly highlighting the role of employers' associations. Although in Madrid CEIM was part of the committee that designed the Regional Innovative Strategy, in general they are not a major player in the design of coordination mechanisms. The participation of FADE in regional dialogue in Asturias, meanwhile, may be seen as a way to counterbalance the power of trade unions on the regional government.

It is clear that the effects of international competitive pressures have been filtered by the interests, priorities and political possibilities of each region, resulting in different ways of controlling labour in order to reduce uncertainty. In the case of Asturias, governing coalitions have sought to co-opt social actors into the decision-making processes of the regional government, as a way of conjugating a competitiveness agenda with a strong trade union movement. In the case of Madrid, weaker trade unions, more dependent on political parties 
than the other way around, and disorganisation of the Left made a more standard neo-liberal path easier to follow.

\section{References (Anonymised references to be added)}

ACESS (2016), Acuerdo para la Competitividad Económica y la Sostenibilidad Social. Concertación social Asturias 2016-2019. Signed by Gobierno del Principado de Asturias, CCOO Asturias, UGT Asturias y FADE. Available at www.asturias.es (accessed 14 December 2016).

AEPA (2013), Acuerdo por el Empleo y el Progreso de Asturias 2013-2015. Signed by Gobierno del Principado de Asturias, CCOO Asturias, UGT Asturias y FADE. Available at www.asturias.es (accessed 14 October 2015).

Aragón, J., Blanco, M., de la Fuente, L., Liceras, L., Puig-Samper, F., Rocha, F. and Santana, M.I. (2008), La concertación social territorial en España. Una aproximación a los Acuerdos Autonómicos (Madrid, Fundación 1 de mayo).

Beugelsdijk, S. and Mudambi, R. (2013), 'MNEs as border-crossing multi-location enterprises: The role of discontinuities in geographic space’, Journal of International Business Studies, 44(5), 413-426.

CESA (2014), Situación Económica y Social de Asturias 2013, Consejo Económico y Social del Principado de Asturias. Available at www.cesasturias.es (accessed 24 October 2015). Coe, N. M., Dicken, P., and Hess, M. (2008), 'Global production networks: realizing the potential', Journal of Economic Geography, 8, 271-295. 
Coe, N.M.; Hess, M.; Wai-Chung Yeung, H.; Dicken P. and Henderson, J. (2004),

‘Globalizing' Regional Development: A Global Production Networks Perspective’, Transactions of the Institute of British Geographers, 29, 4, 468-484.

Coe, N.M. and Yeung H. (2015). Global production networks: Theorizing economic development in an interconnected world (Oxford, Oxford University Press).

Deakin, S., Hobbs, R., Konzelmann, S. and Wilkinson, F. (2005), 'Working corporations: corporate governance and innovation in labour-management partnerships', in M. Martinez Lucio and M. Stuart (eds) Partnership and Modernisation in Employment Relations (London, Routledge).

El Mundo (2012), ‘Aguirre: 'Estos sindicatos caerán como el muro de Berlín’, March 30, 2012. Available at www.elmundo.es

Fuller, C., Bennett, R.J. and Ramsden, M. (2003), 'Organised for inward investment? Development agencies, local government, and firms in the inward investment process', Environment and Planning, 35, 11, 2025-2051.

Gallie, D. (2007), Employment regimes and the quality of work (Oxford, Oxford University Press).

Government of the Community of Madrid (2014), Estrategia Regional de Investigación e Innovación para una Especialización Inteligente (RIS3). Available at www.madrid.org (accessed 10 November 2015).

Government of the Principality of Asturias (2014a), Industrial Strategy for Asturias. Available at www.idepa.es (accessed 14 October 2015).

Government of the Principality of Asturias (2014b) Asturias RIS3 2014-2020. Available at www.idepa.es (accessed 10 November 2015). 
Henderson, J., Dicken, P., Hess, M., Coe, N., and Yeung, H. W. C. (2002), ‘Global production networks and the analysis of economic development'. Review of International Political Economy, 9, 3, 436-464.

IDEPA (2015), Invest in Asturias. Available in: http://www.investinasturias.es (accessed 13 October 2015).

Invest in Madrid (2015), Business Location, Available at www.investinmadrid.com (accessed 13 October 2015).

Jessop, B. (1993), 'Towards a Schumpeterian workfare state? Preliminary remarks on postFordist political economy'. Studies in Political Economy, 40, 1, 7-39.

Köhler, H. D., Arnicke, S., Latorre, P., Agüera Sirgo, J. M., and Vega García, R. (1996), Asturias: el declive de una región industrial. (Gijón, Ediciones Trea).

Kristensen, P.-H., and Zeitlin, J. (2005). Local players in global games: the strategic constitution of a multinational corporation. (Oxford, Oxford University Press).

Lucio, M. M., and Stuart, M. (2005), 'Partnership and new industrial relations in a risk society an age of shotgun weddings and marriages of convenience?’, Work, Employment \& Society, 19, 4, 797-817.

MESS (2011), Encuesta de Calidad de Vida en el Trabajo. Año 2010. Ministerio de Empleo y Seguridad Social. Available at http://www.empleo.gob.es/ (accessed 1 October 2015) Monaghan, S., Gunnigle, P., and Lavelle, J. (2014), 'Courting the multinational: Subnational institutional capacity and foreign market insidership', Journal of International Business Studies, 45, 2, 131-150.

Moreno, L. (2002), 'Decentralisation in Spain’, Regional Studies, 36, 4, 399-408. 
Öbert, P., Svensson, T., Christiansen, P.M., Norgaard, A. S., Rommetvedt, H. and Thesen, G. (2011), 'Disrupted Exchange and Declining Corporatism: Government Authority and Interest Group Capability in Scandinavia’, Government and Opposition, 46, 3, 365-91.

Phelps, N.A. (2000), 'The locally embedded multinational and institutional capture’, Area, 32, 2, 169-178.

Phelps, N.A, and Fuller, C. (2001) 'Multinationals, intracorporate competition, and regional development', Economic Geography, 76, 3, 224-243

Pizzorno, A. (1978), 'Political exchange and collective identity in industrial conflict', in C. Crouch and A. Pizzorno (eds) The resurgence of class conflict in Western Europe since 1968 (London, Palgrave).

Royo, S. (2008), Varieties of capitalism in Spain. Remaking the Spanish Economy for the New Century (Houndmills, Palgrave-McMillan).

Terry, M. (2003), 'Can Partnership' Reverse the Decline of British Trade Unions?’, Work, Employment \& Society, 17, 3, 459-472.

Sánchez Moral, S., Calatrava, A., and Melero Guilló, A. (2008), 'Las funciones comando de Madrid en la economía global: una aproximación a través del proceso de atracción de capital extranjero'. EURE, 34, 101, 25-44.

Vega García, R. (2011), Historia de la UGT (Madrid, Siglo XXI). 